\title{
Amós e a "memória que tudo dita" nas elegias do país das gerais, de Dantas Motta
}

\author{
Vagner Camilo
}

RESUMO: Este artigo tem por escopo examinar as peculiaridades do memorialismo poético de Dantas Motta no segundo livro de sua obra maior, Elegias do país das Gerais. Tais peculiaridades compreendem a visada crítica lançada ao passado; a figuração do eu como poeta-jurista e poeta-profeta; e o discurso elegíaco concebido a partir da fusão da linguagem poética e do jargão jurídico.

PALAVRAS-CHAVE: Dantas Motta; poesia brasileira moderna; elegia; memorialismo; linguagem jurídica.

\footnotetext{
ABSTRACT: This article aims to examine the peculiarities of the poetic memorialism of Dantas Motta in the second book of his greater work, Elegias do país das Gerais. Such peculiarities include a critical view of the past; the figuration of the I as poet-jurist and poet-prophet; and the elegiac discourse conceived from the fusion of poetic language and juridical jargon.
}

KEYWORDS: Dantas Motta, Brazilian modern poetry; elegy; memorialism; legal language. 
A Lourenço Dantas Mota, pela acolhida generosa e pela contribuição decisiva para esta abordagem.

Dantas Motta (1913-1974) teve em seu tempo uma acolhida das mais favoráveis por parte de nomes respeitáveis do Modernismo, como Mário de Andrade e Carlos Drummond de Andrade. Este último é responsável pelo estudo introdutório que integra a edição das poesias supostamente completas do poeta de Aiuruoca. Sob o título geral de Elegias do país das Gerais: poesia completa, foram reunidos os livros Planície dos mortos (1936-1944) e Anjo de capote (1946-1952), além das Elegias do país das Gerais (1943-1958) propriamente ditas, sem esquecer de alguns inéditos e esparsos. ${ }^{1}$

Outros intérpretes de destaque se pronunciaram à época sobre a qualidade excepcional da poesia de Dantas Motta, como Adonias Filho, Manuel Bandeira, Waldemar Cavalcanti, Adolfo Casais Monteiro e Sergio Milliet. Nenhum, entretanto, conseguiu dimensionar tão bem o valor e o alcance poético e sócio-histórico de sua produção como o fez aquele cujos próprios versos são referência decisiva para o poeta das Gerais:

[...] em suas obras mais representativas, Dantas Motta foi principalmente poeta social, no sentido mais livre do termo, isto é, sem se prender a limitações ideológicas que tornam às vezes tão odioso esse tipo de poesia. Poeta social, porque socialmente integrado no meio físico e na sorte de sua coletividade, e empenhado em registrar-lhe as derrotas, a "austera e vil tristeza", como também os assomos de inconformismo e a aspiração, abafada ou visível, de reorganizar-se com justiça, dignidade e liberdade.

Dantas foi, por assim dizer, o proprietário, em nossa poesia, de um estilo e um pensamento crítico-poético que não chamarei de inovadores, no sentido de atribuir conteúdo vanguardista a essa classificação. Seria mesmo o contrário disso, pois lhe repugnavam os malabarismos verbais, as charadas ideográficas, a sofisticação de recursos ópticos que distinguem uma poesia mais decorativa do que substancial. O que ele tinha a transmitir em verso era demasiado importante para se submeter a cânones de uma ilusória inventividade. Pedia elocução não criptográfica ou lúdica. Por isso, achou o dizer adequado, ora grave ora sardônico e mesmo navalhante, mas sintaticamente completo. Creio que o seu verso mais característico seja o das Elegias, com o seu ritmo lento e severo, seu contínuo fluir semelhando ou sugerindo as águas do rio São Francisco, esse rio de onde parecem

1. De acordo com Lourenço Dantas Mota, filho do poeta, outros inéditos surgiram depois da edição de 1988. 
nascer e para onde voltam sempre os poemas de Dantas Motta. Não teve imitadores, que eu saiba, ou, se os teve, passaram despercebidos. ${ }^{2}$

Sem dúvida, esse alcance social diz respeito, notadamente, às Elegias do país das Gerais, composta de cinco partes ou livros, como o autor optou por nomeá-las, as quais fundem, ainda, toda uma diversidade de gêneros poéticos: écloga, poema epistolar, poema dramático etc.

Dos cinco livros que integram as Elegias, interessa abordar tão somente o Solar de Juca Dantas, mais afinado com o tema do dossiê proposto por esta revista. Ele foi, provavelmente, dos últimos a ser composto, embora segundo livro da sequência. Isso levando em conta a datação proposta pelo poeta para sua elaboração: 1954-1957. Para se ter uma ideia, o quinto e último livro desse conjunto foi concebido em paralelo, entre os anos de 1956 e 1958.

O segundo livro vem dedicado ao pai recém-falecido, um motivo a mais para a homenagem:

A meu pai Lourenço Henriques da Motta $\left({ }^{*} 1889+1951\right)$ com este pensamento parafraseado de Péguy: é bem maior o número de santos na obscuridade. ${ }^{3}$

A influência das ideias e dos escritos de Charles Péguy, "o mais perfeito modelo do antimoderno, eterno trânsfuga, agente duplo encarnado"4, sobre Dantas Motta e outros tantos escritores e intelectuais brasileiros dos anos 1930 e 1940 é algo ainda a se aquilatar devidamente, incluindo-se a recepção local dos Cahiers de la Quinzaine, que o poeta e escritor francês dirigiu. ${ }^{5}$ Sobre esse pensamento que o poeta mineiro diz parafrasear,

\footnotetext{
2. ANDRADE, Carlos Drummond de. "Nome a lembrar: Dantas Motta". Trata-se, na verdade, de material publicado originalmente em $O$ Estado de S. Paulo, por ocasião do primeiro aniversário da morte de Dantas Motta, na forma de entrevista concedida a Delmiro Gonçalves. Drummond republicou-o, posteriormente, no Jornal do Brasil em três partes, nos dias 6, 8 e 10 de março de 1979. In: MOTTA, Dantas. Elegias do país das Gerais: poesia completa. Rio de Janeiro: José Olympio; Brasília: INL/Fundação Nacional Pró-Memória (Coleção Resgate, vol. 6), 1988, p. XVI.

3. Para a reprodução dos versos das Elegias, valho-me da edição de 1961 que me parece mais cuidadosa: моттA, Dantas. Elegias do país das Gerais. Rio de Janeiro: José Olympio Editora, 1961, p. 95.

4 compagnon, Antoine. Os antimodernos: de Joseph de Maistre a Roland Barthes. Belo Horizonte: UFMG, 2017, p. 225.

5. Lourenço Dantas Mota confirmou-me que é procedente a influência de Péguy sobre o pensamento
} 
vale mencionar a observação de Claire Daudin, quando afirma que a figura do santo sempre tomou o lugar do militante nos escritos do autor de Mystère des Saints Innocents e de outros tantos mistérios de inspiração medieval. Trata-se, sempre, da questão do agir, de andar e procurar transformar o mundo, buscando, ao mesmo tempo, não se deixar prender pelas "armadilhas da luta política, que Péguy denunciou com lucidez". 6

Sem dúvida, a questão da militância está no horizonte de atuação de Dantas Motta, "moderno cavaleiro andante da jurisprudência a serviço de posseiros sem esperança", como o denominou Drummond. Não se trata, portanto, apenas de uma metáfora projetiva para a militância, mas de um agir traduzido em andança efetiva. Ela surge, também, como uma alternativa mais eficaz às armadilhas da luta política, nas quais Dantas Motta quase se deixou prender quando pretendeu a candidatura como deputado pela UDN... Como bem lembra Drummond, "por felicidade, não tivemos na Câmara o Deputado Dantas Motta", que certamente entraria em choque com "as conveniências partidárias", mas a militância política trouxe resultados decisivos para sua criação poética: deu-lhe "a sofrida experiência, a visão extrafachada dos problemas e figurantes envolvidos em seu jogo. Não houvesse a passagem pela política, talvez sua poesia tomasse outro rumo, descompromissado com o real e o social: um rumo apenas estético".

Esse compromisso do poético com o real e o social deixou marcas evidentes no conjunto das Elegias. No caso do Solar, aparece a todo momento, valendo destacar, a título de ilustração, a passagem em que, suspendendo por instantes a rememoração, o eu lírico se volta, por meio da apóstrofe, à própria poesia, em busca de inspiração para seguir como o canto. Trata-se de uma concepção sui generis de criação, em que se funde poesia, princípio de economia, Maiakóvski, denúncia político-social e conversão cristã de famílias locais oriundas de outras etnias e religiões...

do pai. Destacou, como exemplo, a visão do dinheiro que ambos têm em comum, e indica, como leitura sugestiva para se pensar essa influência, o estudo de Jacques Julliard (L'argent, Dieu et le diable: face au monde moderne avec Péguy, Bernanos, Claudel), intelectual de esquerda e católico, que é autor de uma monumental história da esquerda francesa.

6. Diz ela ainda que tais personagens santificados são, sem dúvida, figuras modelares, "mas para os seguir é necessária uma virtude ainda superior à coragem e ao sacrifício de que Péguy é o herói da luta por Dreyfus em nossa juventude". Ver o estudo biográfico e crítico de Claire Daudin no portal do sítio dedicado ao poeta e pensador francês em <http://charlespeguy.fr/La-dent-du-dieu-qui-mord $>$. 
Ó poesia em cuja forma me adentro, Tornada diária, noturnamente útil, Também princípio de economia, Trabalho por que clama Maiakovski! Infundi-me forças ao canto, Para que eu possa pôr um jesus Nos mínimo, um divino nos chantre, Um sacramento nos coutos, E se interrompam, enfim, Todas essas árvores genealógicas, Que povoaram de desertos o País, De erosões a terra inculta,

De ausências os casebres miseráveis, De dinheiro os Bancos da República,

De ninguém os caminhos morrendo.?

A própria convergência entre o santo e o militante identificada por Daudin nos escritos de Péguy encontra um correlato na identificação do poeta social das Elegias com um dos profetas, conforme se evidenciará adiante.

Antes disso, importa tratar das feições memorialísticas assumidas pelo discurso elegíaco no Solar de Juca Dantas, que também matizam, em boa medida, Sião, o terceiro livro das Elegias do país das Gerais. Limito-me, entretanto, ao segundo livro, a fim de examinar o estatuto da subjetividade lírico-elegíaca, a ficcionalização da voz poética e as atitudes do memorialista face ao passado ancestral, denunciando mais claramente qual o propósito da rememoração que norteia o poema.

Embora apresente traços autobiográficos, o Solar de Juca Dantas se caracteriza mais apropriadamente como memorialismo. Isso porque, para além da história de uma personalidade, a ênfase recai no estatuto testemunhal do $e u$ e no alcance trans-individual dos acontecimentos abordados. ${ }^{8}$ É bem verdade que Gusdorf alega que os dois gêneros de escritas de si não se opõem e chegam mesmo a se confundir em vários casos, uma vez que a tônica na vida individual ou no mundo são extremos em meio aos quais as obras se

7. мотта, Dantas. Op. cit., p. 104.

8. Lejeune, Philippe. Lautobiographie en France. Paris: Armand Colin, 1971, p. 15. 
instalam, oscilando entre um e outro. No entanto, ele próprio reconhece um tratamento distintivo da subjetividade em cada caso: ao passo que a autobiografia contempla a intimidade do sujeito, o memorialismo privilegia sua face pública ou social, bem como suas relações com o horizonte histórico, compondo amiúde o retrato de uma grande personalidade, uma genealogia ou o quadro de relações sociais num dado contexto. ${ }^{9}$

Quando se passa em revista as sete partes que compõem o segundo canto, percebe-se claramente a ênfase dada ao trans-individual, enquanto o eu ganha a cena para revelar não tanto um drama interior, mas o que responde por sua condição ou estatuto social.

O memorialista recorre a um locus clássico nesse gênero de discurso: a casa ancestral. Vários são os poemas, por exemplo, de Drummond, que reportam a esse lugar comum, desde o hamletiano "Viagem na família" (em José), inaugurando a linhagem dos grandes poemas de família, até "O peso de uma casa”, no livro póstumo (Farewell). É possível que Dantas Motta tenha buscado inspiração no exemplo drummondiano ao se apropriar dessa tópica, já que a alusão ao poeta itabirano se faz em mais de um momento do Solar de Juca Dantas. Mas o tratamento dado à "casa solarenga" em que se vê o eu adentrar logo no pórtico do livro é algo bem diverso da culpa familiar que mobiliza o fazendeiro do ar em relação aos desígnios do pai e do clã mineiro.

E entrando esta casa solarenga, dos dantas, digamos,

Perdido no fundo do chamado Ermo dos Gerais,

A candeia à mão alumiando o revés dos sítios,

Pelos caminhos onde os galos mais não cantam..$^{10}$

À primeira vista, pode parecer pretensão nobiliárquica conferir o status de solar à casa ancestral dos dantas, embora o "digamos" (somada ao minúsculo do sobrenome) já relativiza tal impressão, desmentida de vez ao longo dos versos, revelando-se, por fim, quase irônica quando se considera a visada crítica que preside a visitação.

O eu memorialista promove sua visita mais imaginária do que real sintomaticamente com "a candeia à mão aluminando o revés dos sítios", assim como, mais adiante, risca um fósforo "no fundo desta sala/ que em morcegos se ceva". O jogo entre luz e sombra ganha, obviamente, significação maior ou simbólica. Isso não só por trazer à

9. GUSDORF, Georges. Les écritures du moi. Paris: Garnier, 1991, pp. 260-261.

10. мотта, Dantas. Op. cit., p. 97. 
luz o passado ancestral, mas por iluminar racionalmente os alicerces da ordem econômico-social que deram sustentação ao universo rememorado. Portanto o eu já atesta, de saída, o desejo evidente de seguir a contrapelo da história, movido não por um anseio nostálgico de reencontro com o passado ancestral, mas por um impulso desmistificador, buscando iluminá-lo e examiná-lo de uma perspectiva crítica.

O memorialista não se mostra investido daquele poder restaurador que faz o passado aflorar em sua plenitude. A referência aos galos que já não cantam pelos caminhos atestam isso. As remissões ao tempo pretérito vêm sempre marcadas pelo silêncio, pelo abandono e pelas fantasmagorias e imagens de esterilidade -

\section{Morreu o crepúsculo!}

Um sol fantasma de arado e semente defunta,

Que não cativa de seu degredo os campos do sono,

De há muito enobreceu, empoeirado, um fim de tempo.

Nem as cardas doiro - a roca ao lado -

E que as chuvas de junho as nuvens não fiam,

Se abespinham sem mãos humanas que as afaguem,

Visitadas que são, hoje, por vespas e aves noturnas. ${ }^{11}$

Destaque-se, ainda, as alusões ao insulamento, sofrimento, extenuação e morte, exemplificadas pelo momento em que o eu afirma ter preferido jamais ingressar na casa solarenga, feita "de prestígio e solidão" e circundada de soluços, luares mortos, velhos defuntos e secas borboletas:

Prouvera que eu, nesta casa, não entrasse,

Feita que é, toda ela, de prestígio e solidão.

Os muros circundantes que, na várzea,

Se compunham apenas de latim, heras e bibliotecas,

Agora se tocam de outros soluços,

E, sob um luar de mortos minérios,

Carregados do tão doce preceito itabirano,

Começam, de novo, a pastar velhos defuntos,

11. Ibidem. 
À margem de um rio de bois tristes

E secas borboletas que se vão definhando. ${ }^{12}$

Isso sem esquecer do noturno associado às sombras do esquecimento e da morte, extinguindo animais, pastagens, pássaros e divisas:

Enoiteceu o País!

E com a noite sobre as empoeiradas sombras de Sião,

Sem pastagem, sem gado de corte ou de cria,

Este sol também morto de desertos e minérios,

Que extingue das ramagens os derradeiros pássaros,

E mata, por força de uma lei de subsolo,

Dos últimos sítios as derradeiras divisas.

\section{ENOITECEU!13}

Tais signos negativos se disseminam por todo o canto. Seres e costumes evocados pelo memorialista não perdem seu caráter fantasmal, como na passagem em que se rememora os preparativos dos jantares seguidos de música que animaram, outrora, o solar, agora descritos por espíritos envoltos em capuzes brancos, cuja movimentação é comparada a um minueto. É quase uma espécie de recriação moderna da dança macabra, embora sem o sentido original dessa sarabanda medieval que servia como advertência contra a vaidade das distinções sociais. Já aqui, a hierarquia se repõe tal como se dava no passado:

Aqui os espíritos, envoltos em capuzes brancos,

Entram e saem a sala, o alçapão, a despensa.

Num ligeiro curvar de cabeças, como num minueto,

Pelos corredores longos inda se tocam, conduzindo,

Cada qual, a ânfora, a jarra e a toalha de linho.

Sabor de barbas, após a refeição, alimpando-se,

Na pêra, como um brasão, do leite derramado.

12. Idem, p. 101.

13. Idem, p. 107. 
À noite, vazia a sala, são solaus

Que na solfa adormecem os salões de ouro,

E todas as cadeiras, austríacas,

Se movimentam num leve arrastar de pés,

Sob o compasso manso da de balanço, sozinha. ${ }^{14}$

Em face do universo rememorado, tão marcado por essas notas lutuosas, o eu não demonstra qualquer afetividade. Ao contrário, só lhe dirige o olhar distanciado:

Dos sete montes solitários,

Vivendo todos sob a cara tenebrosa do Arpamingos

Que havendo assistido aos enterros de meu avô e bisavô,

De mim não colhem senão este olhar à distância. ${ }^{15}$

Esse distanciamento, somado à atitude desmistificadora, no sentido alegado de não fazer concessão ao passado patriarcal, é algo bastante incomum no memorialismo brasileiro, notadamente o mineiro, em que se alinha Dantas Motta. Só por isso, ao invés do esquecimento a que tenderam a ser relegadas, as Elegias do país das Gerais já mereciam um lugar de destaque, quando posta à contraluz dessa vertente tão forte na literatura brasileira.

Basta notar o quanto o poeta se afasta de certas ambivalências do memorialismo de um Pedro Nava, por exemplo. Não há, como neste, pretensões nobiliárquicas e orgulho genealógico, nem o autoenobrecimento do memorialista por ser o detentor do poder de preservar a história dos antepassados. Também não se verifica no autor das Elegias, como no de O baú de ossos, a adoção da imagem ou da identidade do herdeiro, seja do patrimônio econômico-financeiro, seja da tradição e da cultura familiares. ${ }^{16} \mathrm{E}$ se o "narrador das Memórias encarna um modelo positivo da classe superior brasileira que decaiu com a crise das oligarquias"; se ele representa "um autêntico filho-família

\footnotetext{
14. Idem, pp. 97-98.

15. Idem, p. 98.

16. MELo, Juliana Ferreira de. "A construção de si como um herdeiro: Pedro Nava e os episódios de Baú de ossos". <http://alb.org.br/arquivomorto/edicoes_anteriores/anais16/sem1opdf/sm1osso8_o6.pdf>, pp. 1 e 5).
} 
da burguesia nacional" imbuído da "missão de pensar o país". ${ }^{17}$ em Dantas Motta esse compromisso persiste, de certo modo, embora sem o status do primeiro, pelo menos na ficcionalização que os versos promovem, ao que se acresce o intento maior dos versos memorialísticos: a denúncia dos abusos e desmandos dessa classe.

Ao invés do herdeiro, o memorialista do Solar de Juca Dantas insiste na condição de declássé e no desprezo absoluto pelo lastro ancestral ou, em suas próprias palavras, pelo "transunto de velhas glórias". É o que se vê no autorretrato extremamente pungente do doutor deficitário, chegando mesmo à posição de indigência, ainda que se trate de recurso retórico para hiperbolizar a distância social que o separa de seu passado familiar. A condição de decadência é acentuada no detalhe, com a caspa pontilhando os ombros desse mendigo, a quem só resta, impotente, o direito ao choro:

Tarde já. Os fruitos e as crianças possuíam, Nas primaveras frustras que então passei a ser,

Um sabor de saudade no mendigo que hoje sou,

A despeito de transunto de velhas glórias

E humanas lidas. E da caspa em desuso

Que pontilha de grisalho meus ombros chovendo,

Deflui esta decadência de lágrimas sem lastro,

Dando ao título de doutor de Sião

Este ar deficitário de despesa,

Que busca, na ausência de terras e de teres,

E na paciência com que suporto outros coronéis,

O sentido de sua própria escravidão.

Desse mundo não sou. E nem lhe temo a noite.

A noite com suas lenternas e seus ladrões,

Terremotos e valhacoutos.

Temo sim o dia que dela nasce,

17. AGUIAR, Joaquim Alves de. Espaços da memória: um estudo sobre Pedro Nava. São Paulo: Edusp/FAPESP, 1998, p. 208). De acordo com Eneida Maria de Souza (Pedro Nava, o risco da memória. Juiz de Fora: funalfa, 2004), "essa missão correspondia ao projeto cultural de uma geração que se colocou como porta-voz dos anseios populares, a elite intelectual modernista, voltada para o conceito de nação como resultado de um trabalho planejado de cima para baixo, respeitando hierarquias de ordem social e política” (p. 29). 
E com ele a burra de dinheiro, agasalhada e fiel,

Cheia dos terrores noturnos de ontem,

Contendo, ensimesmadas, as mesmas manhãs,

Plásticas e portáteis de hoje,

E em que se enfeixam, de uma só vez,

O gado, a servidão de passagem, a infância,

O luto, a vida e o direito de chorar. ${ }^{18}$

Em outros versos, reaparece essa ênfase na condição de espoliação ou, como ele dirá ainda, no "fadário da inconformada pobreza", que o obriga a se sujeitar ao poder e desmando dos coronéis, equiparando-o, no grau de privação extrema acima indicado, à condição escrava... Veja-se mais esta passagem que também explora de forma contundente as aperturas econômicas e privações de eu:

Entanto fugido não tenho

À paz que em agonia se ensaia.

Nem forçado a porta do dinheiro,

Incidente e escusa,

Que rareia de gente a ampla solidão da posse.

Enoiteceu o País! [...]

E com a noite do País

Enoiteci eu que encontro,

No pagamento da mora,

O meu sustento, e nas bocas,

Encarvoadas e tristes,

Como de filhotes implumes,

Com os bicos abertos à vastidão do mundo,

Este pão de silício,

Vivendo já a um sol doutro hemisfério. ${ }^{19}$

18. мотта, Dantas. Op. cit., p. 106.

19. Idem, p. 107. 
Voltando ao traço diferencial, que é a mirada crítica do memorialista, ele se torna tanto mais evidente, logo que se abre o segundo livro, na menção ao corpo vasculhado do morto apartado de seus bens, em versos cuja força é garantida não só pelo poder das imagens, mas pelos jogos aliterativos:

E vasculhando vou, na memória que tudo dita,

O corpo morno do morto, dos seus bens apartado,

No instante justo, preciso, em que a janela do quarto,

Com a empanada, a luz, o vento e o gosto da injeção,

Noite escura de vaca e herança é. ${ }^{20}$

Nesse trecho, a referência aos bens dos quais o morto se mostra apartado e à herança já sinaliza um traço marcante na linguagem, no discurso e na perspectiva adotadas por Dantas Motta, que introduz, por assim dizer, um dispositivo jurídico ao focalizar o passado, produto, sem dúvida, de sua formação e atuação profissionais. O jargão jurídico invade o domínio poético num híbrido inaudito em nossa tradição. Isso faz de seu memorialismo uma espécie de processo judicial movido contra o passado, promovendo concomitantemente um inventário às avessas.

Sob certos aspectos, esse memorialismo alimentado pelas escrituras, que dominam toda a noite densa do País (p. 75), e demais documentos de posse e de compra e venda, faz lembrar o maior poema de família de Drummond, dado a lume poucos anos antes: "Os bens e o sangue". Talvez sob o impacto desse poema de Claro enigma (1951), Dantas Motta tenha composto, deliberadamente ou não, o Solar de Dantas Motta, lançando mão de um procedimento estilístico formal afim ao do poeta itabirano.

Sabe-se que desde a primeira publicação do poema na Revista Anhembi, "Os bens e o sangue" foi concebido por Drummond a partir da "leitura de um maço de documentos de compra e venda de datas de ouro no Nordeste de Minas Gerais", pertencentes à sua família desde 1781, quando adquiridas pelo seu antepassado, "capitão João Francisco de Andrade, que os transmitira a um seu sobrinho e sócio, o major Laje" (ambos expressamente evocados nos versos). "Diz Eschwege que as lavras de João Francisco, em 1814, produziram mais de três mil oitavas de ouro. A exploração declinou com o tempo, e

20. Idem, p. 97 . 
por volta de 1850 vemos os donos se desfazerem de jazidas e benfeitorias". ${ }^{21}$ O poema se ocupa, justamente, desse momento em que os antepassados se desfazem das lavras, dando início ao processo de espoliação do patrimônio e decadência familiares.

Um dos aspectos distintivos da dicção, gênero e estilo empregados em "Os bens e o sangue", por associação mesmo a esses documentos que inspiraram os versos, é a mimese da linguagem cartorial ou do estilo dos documentos de transação comercial do século XIX, parodiados com humor e poesia, embora revestidos de um fundo fatalista, agregando uma estrutura típica da tragédia para encenar o conflito dramático do herói com os antepassados.

A dimensão de tragédia atravessada de ironia foi uma vez examinada por Correia. ${ }^{22}$ Busquei retomá-la em outro momento, desdobrando-a em função do vínculo original da tragédia com os autos processuais - conforme o demonstraram Jean-Pierre Vernant e Walter Benjamin -, para encenar nos versos e no palco da memória, o julgamento do herói gauche pelo tribunal do clã mineiro. ${ }^{23}$

Ora, o que me parece característico de o Solar de Juca Dantas é também a apropriação da linguagem cartorialesca, não com o intuito paródico de Drummond, mas nem por isso isenta de uma atitude igualmente distanciada e irônica da parte do eu lírico. E ainda que não dialogue com a tragédia, a elegia de Motta não deixa de ser também uma recriação poética de um auto processual investido contra o passado. Não falta mesmo a denúncia da índole mercantilista, que Drummond expunha na boca de seu antepassado Joaquim Fernandes.

Pode-se falar de uma devassa simbólica, para fazer jus ao passado inconfidente associado à figura do capitão de auxiliares e guarda-livros Vicente Vieira da Motta, "um dos condenados da Inconfidência pelo crime de silêncio (não contou às autoridades que Tiradentes conspirava)", segundo informa Drummond. ${ }^{24}$ Esse personagem histórico é, aliás, expressamente evocado nos seguintes versos, como se se tratasse de um antepassado, embora não haja registro que o comprove:

21. Apud camilo, Vagner. "No tribunal do clã mineiro: culpa familiar". In: Drummond: da Rosa do povo à rosa da trevas. Cotia: Ateliê Editorial/ANPOLL, 2005, pp. 267-68.

22. CORREIA, Marlene de Castro. “Tragédia e ironia em 'Os bens e o sangue”'. Littera. Rio de Janeiro, set-dez 1972. 23. CAMILO, Vagner. Op.cit., pp. 263-276.

24. Drummond afirma esse parentesco direto, mas, equivocadamente, fala em Vicente "Ferreira" Mota (ANDrade, Carlos Drummond de. "Nome a lembrar: Dantas Motta”. In: мотTA, Dantas. Op. cit., p. XVI-XXIII). O filho do poeta, Lourenço Dantas Mota, entretanto, diz desconhecer qualquer vínculo familiar com esse personagem, o que não impediria o pai de sugerir, ficcionalmente, tal parentesco. 
Que os demais, deixando morrer de sede e fome, Às margens do Rio Lenau, o Capitão de Auxiliares Vieira da Mota, perderam de mim as suas feições. ${ }^{25}$

Volto ao dispositivo jurídico, que mobiliza diferentes recursos e referências temático-formais empregados nos versos. A própria ênfase na dimensão espacial, com a evocação da casa e da geografia local como fundamento físico da rememoração, atravessadas que são pelas relações de classe, faz pensar no conceito de espaço jurídico de Halbwachs (aliás, também formado em direito). Para o autor de A memória coletiva, não se trata de "um ambiente [...] vazio que simboliza apenas uma possibilidade indefinida de relações jurídicas entre homens". Conforme esclarece uma comentarista do grande sociólogo francês, a apreensão dessa noção de espaço corresponde à necessidade de inscrever as relações jurídicas em um quadro concreto:

As relações entre homens não se dão no imaterial. Os diferentes modos de agenciamento dessas relações interindividuais, a princípio, coletivas e sociais, em seguida, que propõe todo sistema de direito, aparentam ser muito abstratas, até fictícias, para Halbwachs. A ancoragem da relação jurídica no real parece, assim, necessária não para determinar a natureza das ligações que os indivíduos tecem entre si, mas para assegurar a permanência, a continuidade e o seu reconhecimento na e pela sociedade.

A simbolização dessas ligações pelo atestado jurídico "escrito" não teria, então, sentido e não provocaria efeito a não ser em duas condições. Por um lado, esses elos devem "enraizar-se", isto é, devem ter um suporte material, uma implantação no "chão"; eles devem ser concretizados, executados, realizados; eles devem se inscrever nas terras, nos lugares ou se estruturar em imóveis, edifícios ou prédios. Por outro lado, a representação espacial e tangível dessas ligações deve suscitar em cada um dos protagonistas envolvidos, de uma maneira ou de outra, pelas relações que elas induzem, uma imagem estável que fixa e repara a memória. ${ }^{26}$

No Solar, o dispositivo jurídico mobiliza, ainda, a identidade assumida pela voz poética. A autorrepresentação do eu como poeta-jurista - na falta de melhor termo - comparece

25. мотта, Dantas. Op. cit., p. 108.

26. Koubi, Geneviève. "L’espace de la mémoire collective sans le droit public". In: DÉLOYe, Yves e HAROUCHE, Claudine (dir.). Maurice Halbwachs: espaces, mémoire et psychologie collective. Paris: Sorbonne, 2004, p. 125. 
em vários momentos, a começar pela imagem de uma espécie de duplo do memorialista: o neto bacharel do Barão de Aiuruoca, cafeicultor e político proeminente do Império, com atuação destacada no Vale do Paraíba e na região de Minas onde nasceu Dantas Motta. O neto surge "de preto, grisalho e triste", ao fundo do quadro a óleo do avô, caraterizado de forma pouco enobrecedora para um ilustre fundador da cidade natal do poeta... Se as imagens dos avós contrastam substancialmente, o mesmo não se pode dizer em relação à do neto do Barão e à do de Juca Dantas, já porque este diz se "adestrar" naquele:

Um fósforo riscado no fundo desta sala

Que em morcegos se ceva, mostra, medonho e terrível,

Nos seus trejeitos de saudade, raiva e bufoneria,

O quadro a óleo do Barão de Aiuruoca

Da parede saindo. Ao fundo, de preto, grisalho e triste,

O neto varão - doutor de Sião -,

Removendo a escrivaninha,

Entre Caraças, Horacius e Virguilius

Busca, como buscado tem, na infância das tenças,

$\mathrm{O}$ fideicomisso, o usufruto, o adjutório,

Inclusive aquelas cartas outras de sesmeiros,

Com o gado invisível pastando. ${ }^{27}$

A passagem, aliás, é um bom exemplo da incorporação do jargão jurídico no domínio do poético, no misto invulgar referido há pouco. Eis, agora, o retrato bacharelesco do próprio eu memorialista, o doutor ou escriba do Sião depauperado, às voltas com o exame e a denúncia das escrituras que fizeram engordar a fortuna dos antigos senhores à custa da exploração e, ironicamente, sob a bênção do Senhor...

Porque tu, exílio de seminarista e rosa, em que me adestro,

Que toda fazenda de um padre precisa por garantia,

Sabendo vais da inconformada pobreza o meu fadário,

Dos pássaros inumeráveis à boca tímida

27. моттA, Dantas. Op. cit., p. 99. 
Esta solidão gentil de roupa preta e tumultuosa,

Sobretudo este sol longínquo e há tanto tempo morto,

Sumindo, neste instante, nos socavões da serra,

De cujo rés-do-chão esta agora vos escrevo.

Doutor ou escriba de Sião - sei lá! -

Neste inferno que de montanhas duras se alimenta,

Vivo de reescrever, de novo, as Tábuas da Lei?

De ressurgir as datas e os prazos que engordaram

De vez os mais afortunados? De libertar as almas

Prestigiadas de negros demônios, acorrentando-se no escuro?

Vivo, sim, de, à luz dos palimpsestos,

Examinar aquelas escrituras prescritas e pretéritas,

Produtos de tanta gana e tanto roubo,

Lavradas todas em nome de Nosso Senhor Jesus Cristo,

e onde os homens,

“NOS SAIBAM QUANTAS ESTA VIREM

OU DELA NOTÍCIAS TIVEREM,” $[. . .]^{28}$

Nesse sentido, Dantas Motta contraria o sentido histórico que o bacharel assumiu em nossa tradição, na sua aliança acrítica com os interesses da classe de mando. Obviamente, penso no famoso capítulo de Sobrados e mucambos em que Freyre examina o bacharelismo como habilitação para o exercício do poder e, em vista disso, o prestígio crescente do título de doutor no contexto oitocentista, constituindo como um "aristocracia de beca e toga". ${ }^{29}$ Penso, também, nas passagens de Raízes do Brasil, em que Sérgio Buarque explora a erudição sobretudo formal e exterior, puro verniz social, evidenciado no apego bizantino aos livros, visando apenas a dignificação e o enaltecimento daquele que ostenta o anel de grau ou a carta de bacharel. Nos versos acima, ainda que o bacharelismo pareça surgir, notadamente no caso do neto do Barão, como o destino natural dos filhos das elites proprietárias, não raro alheios ao universo rural e à inabilidade no trato com a terra e o gado, já não se trata mais, em especial no caso

28. Idem, pp. 99-100.

29. Freyre, Gilberto. "Ascensão do bacharel e do mulato". In: Sobrados e mucambos: decadência do patriarcado rural e desenvolvimento do urbano. Rio de Janeiro: José Olympio, 1951, v. 3, pp. 951-1039. 
do memorialista déclassé, de um bacharelismo epidérmico e acrítico, dominado pelo espírito de cordialidade. ${ }^{30}$

Veja-se, ainda, como o referido dispositivo mobiliza a própria linguagem poética, muito embora Drummond, que chegou a atentar à influência jurídica na poesia de Dantas Motta, tenha acabado por minimizar consideravelmente sua importância:

\begin{abstract}
Ainda sobre influências, o amigo indaga se, a meu juízo, a formação e a prática jurídica terão marcado a linguagem e a temática do poeta Dantas Motta.

Respondo que sim, por fazerem parte desse cotidiano que o cercava, não me parecendo entretanto que deixassem marca fundamental. Ao lado do Antigo e do Novo Testamento, a grande presença foi a terra, o meio urbano-rural em que Dantas viveu. O problema $\mathrm{n}^{\circ} .1$ do homem do interior há de ser naturalmente a terra, que vai gerando problemas: a posse, contestada e defendida em demandas ou a tiro e foice; divisas, servidão de água, queimada, furto de animais, colheitas frustradas pelas condições climáticas ou pelas pragas de insetos, os financiamentos discutidos, as hipotecas, a preocupação de transmitir a terra aos filhos, e o temor de perde-la até por falta de pagamento de imposto. No caso, o advogado era também poeta, e aquele servia a este, dando-lhe a base de conhecimento real que os poetas das grandes cidades só alcançam por ouvir dizer. ${ }^{31}$
\end{abstract}

O fato é que, a meu ver, o poeta e o advogado se encontram nas Elegias, notadamente neste segundo livro, fazendo com que poesia, jurisprudência e economia convirjam neste memorialismo suis generis que revê o passado pela lógica da acumulação do capital, de um lado, e da concomitante espoliação, de outro. É o que marca a diferença ou mudança de ênfase na passagem do primeiro para o segundo livro das Elegias. Naquele, o poeta-jurista, a fim de denunciar os problemas elencados acima por Drummond, eleva-se em defesa dos mais fracos e deserdados, delegando a voz poética a retirantes, posseiros e pequenos sitiantes, expulsos de suas terras, seja pela exploração imposta pelo grande proprietário ao meeiro no regime de arrendamento, seja pela cobiça do fazendeiro poderoso que, cioso de estender os domínios de terras, arremata por baga-

30. Ver "O sentido do bacharelismo", no capítulo vi, "Novos tempos", de Holanda, Sérgio Buarque de. Raízes do Brasil. Rio de Janeiro: José Olympio, 1988, pp. 113-125.

31. Andrade, Carlos Drummond de. "Nome a lembrar: Dantas Motta", op. cit.: p. Xxi. 
tela o sítio do pequeno proprietário, com a conivência de uma lei corrupta, nunca à medida dos direitos dos mais despossuídos. Já neste segundo livro, o poeta-jurista se volta diretamente contra a memória dos antigos proprietários a que se ligaram, de algum modo, seus antepassados, a fim de denunciar a cobiça e a avidez da exploração com que compuseram seu capital, sempre em detrimento do escravo ou do homem livre pobre.

A denúncia se estende ainda à venalidade da igreja, cúmplice da acumulação patriarcal e da concomitante espoliação que ela implicou, conforme se viu nos versos supracitados e em mais esta passagem, posta logo na abertura do segundo livro:

Percebo um cheiro de inventário,

Um gosto de arrecadação tocado a padre,

A crucifixo e a capa d'asperges. ${ }^{32}$

É curioso, nesse sentido, que o mesmo poeta-jurista empenhado em acusar esse aliciamento, valha-se do discurso bíblico para promover sua denúncia e condenação de tal acumulação desmedida e tal cumplicidade venal... Isso se verifica tanto no plano formal (i.e., no da linguagem e do estilo), quanto numa das personas assumidas pela eu lírico. No primeiro caso, a dicção poética de Dantas Motta, como notou Drummond e outros intérpretes, é resultado da fusão do discurso bíblico com o jargão jurídico. É curioso, nesse sentido, atentar-se ao modo como, no Solar, o poeta emprega o termo escritura no duplo sentido, bíblico e jurídico.

Já no segundo caso, a ficcionalização da voz poética leva o eu lírico a assumir, a dada altura, a identidade de Amós, o profeta que denunciou, de forma simples e direta, a riqueza desmedida de uns e a miséria excessiva de outros. É o que se vê na seguinte passagem, onde emerge o poeta como profeta, num cenário de terra devastada e desértica, já investindo contra cruéis patrões:

Nem sabem que o pão, como as agendas,

Têm lá suas origens,

Divididas nunca em propriedades de cruéis patrões,

Mas côdeas e bocas, outonos e estações.

32. мотта, Dantas. Op. cit., p. 97. 
E, à medida que a terra envelhece e morre,

Suas árvores se vão tornando ridicas e maninhas,

Com pássaros empoeirados, sem campina, e sem alfanje.

É um terreno de insetos e de bíblias,

De que saio, profeta menor, Amós digamos,

Buscando a perdida infância com o que me renovar,

$\mathrm{E}$, assim, informar este duro homem que hoje sou,

Sempre sob o signo deste País, denso e misterioso,

Tão rico de facúndias, quão de desertos,

E em cujas solidões tanto me excito,

Para buscar, nas reentrâncias dos mesmos Tigres,

Dos mesmos Jordãos e dos mesmos Eufrates,

As razões doutros Tetrarcas e doutras Galileias. ${ }^{33}$

No conjunto das Elegias do país das Gerais, essa identificação do eu lírico com o profeta menor torna a reaparecer na seguinte passagem do terceiro livro, Sião, dentro do mesmo espírito de crítica social:

E, então, os diamantes inexistentes, sem raiz e sem valia,

Vos não perderiam, tornando-vos longos como ciganos,

Pois que os profetas, de que provenho desde Amós,

Inclusive Ezequias, que por águas, escorpiões e desertos me ferem,

Aqui, tibetanos, talvez se não plantassem,

$\mathrm{E}$ as fortunas se não escorreriam da pedra-sabão, da lepra. ${ }^{34}$

Herbert Marks identifica a voz de Amós, "suprema entre os Doze", como sendo a "da indignação honesta", na "busca diligente por justiça social". Lembra que Blake viu nele o "gênio da profecia", cuja "retórica magnífica", antitética, é interpretada nos seguintes termos:

É difícil compreender essa fúria extática do negativo. De onde vem a energia para a ira do profeta? Como e por que ele insiste, contra todas as probabilidades, em rejeitar a aco-

\footnotetext{
33. Idem, p. 100.

34. Idem, p. 119.
} 
modação? Falar do contexto social da profecia, de escolas ou grupos de suporte, apenas evita a questão central de um poder poético que, em sua intensidade alucinatória, lembra a megalomania, as palavras mágicas e ideias obsessivas do paranoico. Como as ilusões paranoicas, o zelo profético pode ser uma função da repressão ou, mais precisamente, dos fracassos da repressão, que permite que a vontade abra caminho em formas disfarçadas e elabore, no lugar do mundo proibido, suas próprias estruturas de aflição psicológica e social. A agressão, na raiz de todo entusiasmo poético, tem sido reconhecida desde Longino, o primeiro crítico literário a mencionar a Bíblia, mas fala mais alto nos profetas, os quais, eles próprios aflitos, aplicam sua palavra a tudo que os cerca. A indignação inclui a crítica social, mas não se limita a ela. A ira poética de Amós estende-se à própria poesia, consumida com outras expressões de capacidade humana em um nivelamento universal $[\ldots] . .^{35}$

Sem dúvida, Dantas Motta não empresta totalmente o tom indignado, nem o estilo simples e direto de Amós. Ao contrário, sua linguagem, ainda que flerte com o discurso bíblico, é mais altissonante, sofisticada, elaboradíssima, fundada numa sintaxe complexa, predominantemente hipotática, ao contrário da parataxe dominante na forma bíblica. Sua seleção lexical é elevada, não raro recheada de arcaísmos, embora mesclada, por vezes, de termos populares. Isso sem esquecer da abundância de recursos retóricos e tropos próprios do gênero poético.

Também não diria que haja aqui propriamente um tom indignado como o de Amós, mesmo tendo-se a revolta como fundamento da denúncia social. Esse tom indignado só viria a ser empregado nos versos dedicados, anos depois, a Tiradentes.

Se não encontramos aqui a "retórica magnífica", a "fúria extática do negativo", a intensidade paranoico-obsessiva a que chega a "ira poética de Amós", exacerbando a referida agressão longiniana que está na raiz da poesia, é talvez porque Dantas Motta tenha buscado alguma inspiração para o retrato do profeta não só no Velho Testamento, mas na recriação plástica, mineira, de Aleijadinho, cujo Amós difere dos demais profetas acrobatas que, com seus gestos loucos, imprecatórios, encenam, dramaticamente, seu balé sacro no adro de Congonhas. ${ }^{36}$

35. Alter, Robert \& Kermode, Frank (org.). Guia literário da Bíblia. Trad. Raul Fiker ão Paulo: Ed. Unesp, p. 238.

36. BAZIN, Germain. O Aleijadinho e a escultura barroca no Brasil. Tradução de Mariza Murray. Rio de 

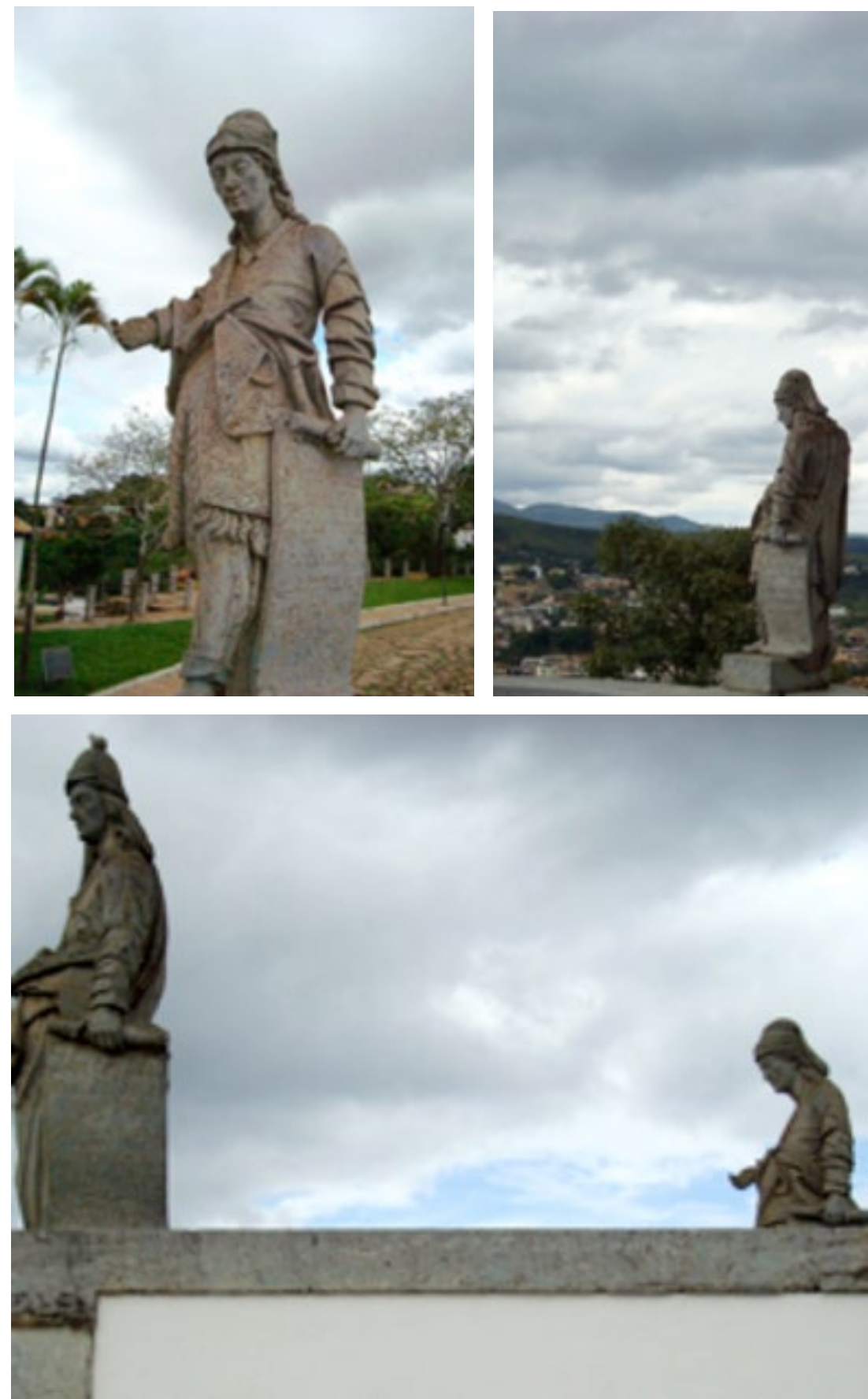

Fotos de Alexandre Josué, 2008.

Teresa revista de Literatura Brasileira [19]; São Paulo, 2018 • 33 
Essa diferença se faz notar tanto no tipo físico, quanto na indumentária:

Seu rosto largo e imberbe tem expressão calma, quase bonachona, como convém a um homem do campo. Está vestido com uma espécie de casaco debruado de pele de carneiro, alusão à sua condição de pastor e traz na cabeça um curioso tipo de gorro, de forma semelhante ao que usam [...] os camponeses portugueses da região do Alentejo. ${ }^{37}$

Essa condição de pastor do profeta (tal como já o figurara Girolamo Lombardo na Santa Casa de Loreto, conforme lembra Bazin) é reiterada expressamente na inscrição entalhada no filactério que ele porta, denunciando, ainda, seu propósito claro de investir contra "os proprietários das classes dominantes, excessivamente locupletados de riquezas, enquanto os pobres morriam à míngua". ${ }^{8}$

Não deve ser à toa que a menção à Amós nos versos de Sião faça referência à doença que mutilou Aleijadinho e à matéria pétrea em que entalhou seus profetas ("E as fortunas se não escorreriam da pedra-sabão, da lepra"). Se for justa essa aproximação com o Amós de Congonhas do Campo, Dantas Motta também nisso parece se aproximar de Drummond, quando este sustenta a polêmica mineiridade dos doze profetas em "Colóquio de estátuas". ${ }^{39}$

Seja qual for a configuração e ânimo de que se mostra investida a poesia de Dantas Motta, este Amós das Gerais, o fato é que ele persiste, tal como seu grande modelo bíblico, na denúncia da avidez dos grandes e da venalidade da justiça, ansiando que "o direito corra como a água e a justiça como um rio caudaloso!" (Am 5:24) - o que, no caso das Elegias, corresponderia, efetiva e não metaforicamente, às águas do São Francisco, de que se ocuparão mais detidamente o quarto livro das Elegias do país das Gerais.

Outros aspectos mereceriam destaque nesse livro ímpar que integra uma obra toda ela excepcional. É o caso da referência aos colonos e às "novas heranças" (p. 79) que marcam o empenho genealógico do eu no Solar de Juca Dantas, a despeito da intenção denunciadora, marcada de negatividade, de Dantas Motta, caminhando, o tempo

Janeiro: Record, 2 ed, pp. 307-309.

37. Oliveira, Myriam Andrade Ribeiro de. Aleijadinho: passos e profetas. Belo Horizonte: Itatiaia; São Paulo: Editora Universidade de São Paulo, 1984, p. 65.

38. Ibidem.

39. ANDRADE, Carlos Drummond de. Passeios na ilha: divagações sobre a vida literária e outras matérias. São Paulo: Cosac Naify, 2011, pp. 57-59. 
todo, num jogo entre memória individual e histórica, familiar e coletiva, nos termos de Halbwachs e fundando, assim, uma identidade comunal. Essa dimensão, entretanto, exigiria uma análise mais detida, reservada para outra ocasião.

Por ora, encerro a presente abordagem remetendo ao fecho fantástico do próprio poema, que torna a evocar a figura do avô materno do poeta, político e coronel José Francisco Corrêa Dantas, vulgo Juca Dantas ${ }^{40}$, cuja solar dá nome ao livro. A figura avoenga, aliás, aparece só no título e nestes versos finais. Seu vulto e o da esposa saem de cena a cavalo, numa montaria fantasmática, rumo a qualquer ermida. A cidade natal, biblicamente identificada como Sião, que não pertence mais aos antigos moradores, acaba dominada por soturnos demônios, enquanto os anjos passam de raspão pelas paradoxais "negras virtudes" do eu... Este observa Sião de forma mais distanciada e do alto.

O memorialista encerra sua evocação do passado num derradeiro jogo de luz e sombra, em correlação com os versos de abertura. É uma espécie de imagem-síntese do segundo livro, como breve, luminoso e lúcido interregno memorialístico no conjunto das Elegias, antes de se apagar em definitivo...

O que era meu e vosso não são mais nossos,

Salvo os fantasmas desses cavalos,

De lombilho um e silhão outro,

Conduzindo nas noites menos vigiadas,

Os vultos de José Francisco Correa Dantas

E Josefina Emília da Silva Dantas,

Mas que, à medida que passam rumo a qualquer ermida,

Vão sendo, nas montanhas anchas e duras,

Substituídos por demônios pelados, rindo.

40. Esclarece Lourenço Dantas Mota: "Juca Dantas é meu bisavô materno (pai de minha avó). Seu nome é José Francisco Corrêa Dantas. Foi vereador em várias legislaturas, com algumas interrupções, de 1890 até 1927, quando chegou a presidente de Câmara. Foi de tenente (primeira legislatura) a coronel da Guarda Nacional. É da família Paula e Silva, que tem ramificações no Vale do Paraíba (o vai e vem entre essa região e o sul de Minas é comum em muitas famílias, desde a Colônia), inclusive com a família de Rodrigues Alves, pelo que posso concluir da biografia escrita pelo Afonso Arinos, casado com uma neta do presidente. Meu pai, se sabia disso, nunca disse nada a respeito. Contam os velhos parentes que houve uma desavença na família, que se dividiu em três: uma manteve o Paula e Silva, outra adotou o sobrenome Benfica e meu bisavô escolheu, não sei por que, o Dantas, muito mais comum no Nordeste que em Minas." 
Longe, os anjos continuam a passar de raspão

Sobre as minhas negras virtudes.

E como um anjo nostálgico,

No seu enfado de Paraíso,

Ou soturno demônio,

Rindo, liberto, da agonia da terra,

Sião eu vejo, lá embaixo,

Com as luzes se acendendo,

Para morrer. ${ }^{41}$

Vagner Camilo é professor associado de Literatura Brasileira na usp e autor de Drummond: da Rosa do Povo à rosa das trevas (Ateliê Editorial/AnPoll 2000).

41. моттA, Dantas. Op. cit., pp. 108-109. 